\title{
BIOMASS AND CRUDE PROTEIN OF TWO FORAGES FERTIGATED WITH TREATED DOMESTIC
} SEWAGE

Giovanni de Oliveira Garcia ${ }^{1}$, Michelle Machado Riggo ${ }^{2}$, Roberto Avelino Cecílio ${ }^{3}$, Edvaldo Fialho dos Reis ${ }^{4}$, José Guilherme Bergamin Mellere

\begin{abstract}
The reuse of wastewater in agricultural activities has been identified as alternative to final disposal of minimal risk to the environment. Accordingly, in order to assess the yield and crude protein content of forages Tifton 85 (Cynodon spp.) and Marandu grass (Brachiaria brizantha) fertigated with treated domestic sewage compared with those grown with mineral fertilizer, two split plot experiments were set: one with each species at $5 \times 3$ factorial arrangement and five repetitions. The factors in the plots corresponded to five treatments, one fertilized with mineral fertilizer in which was applied $40 \mathrm{~kg} \mathrm{ha}^{-1}$ of nitrogen and four fertigated with treated domestic sewage in the dosages of 20, 40, 60 and $80 \mathrm{~kg} \mathrm{ha}^{-1}$ of nitrogen and, three plant sections in the subplots. After each section the plant material had its green mass determined and then sent to the laboratory for measurement of dry mass. Also in the laboratory, the crude protein content was determined. The application of treated wastewater used in the form of fertigation resulted in increased biomass and crude protein reflecting better nutritional value of forages studied.
\end{abstract}

Keywords: Grasses. Animal nutrition. Water reuse.

\section{RESUMO}

\section{BIOMASSA E PROTEÍNA BRUTA DE DUAS FORRAGEIRAS FERTIRRIGADAS COM ESGOTO DOMÉSTICO TRATADO}

A reutilização de efluentes em atividades agropecuárias tem sido apontada como uma alternativa de destinação final de mínimo risco para o meio ambiente. Nesse sentido, com o objetivo avaliar o rendimento e o teor de proteína bruta das forrageiras Tifton 85 (Cynodon spp) e Capim Marandu (Brachiaria brizantha) fertirrigadas com esgoto doméstico tratado comparadas com aquelas cultivadas com adubação mineral, foi montado dois experimentos em parcelas subdivididas, um com cada espécie, no esquema fatorial 5x3, com cinco repetições. Os fatores nas parcelas corresponderam a cinco tratamentos, sendo um fertilizado com adubação mineral, no qual foi aplicado $40 \mathrm{~kg} \mathrm{ha}^{-1} \mathrm{de}$ nitrogênio e quatro fertirrigados com esgoto doméstico tratado, nas dosagens de 20, 40, 60 e $80 \mathrm{~kg}^{\text {ha }}{ }^{-1}$ de nitrogênio e, nas subparcelas, três cortes das plantas. Após cada corte, o material vegetal teve sua massa verde determinada e, em seguida, foi encaminhado ao laboratório para quantificação da massa seca. Também em laboratório, foi determinado o teor de proteína bruta. A aplicação do esgoto doméstico tratado utilizado sob a forma de fertirrigação proporcionou, nas forrageiras, aumento da biomassa e proteína bruta, refletindo melhor valor nutritivo das forrageiras estudadas.

Palavras-chave: Gramíneas. Nutrição animal. Reuso de água.

Recebido para publicação em 14/07/2015. Aprovado em 27/06/2016.

1 - Eng. Agrônomo, Doutor em Eng. Agrícola, Prof. Adjunto, Depto. de Engenharia Rural, UFES. E-mail: giovanni.garcia@ufes.br

2 - Bióloga, Metre. Programa de Pós-Graduação em Meio Ambiente, UERJ. E-mail: michelle.rigo@gmail.com

3 - Engenheiro Agrícola, Doutor em Eng. Agrícola, UFES. E-mail: roberto.cecilio@ufes.br

4 - Engenheiro Agrícola, Doutor em Eng. Agrícola, UFES. E-mail: edreis@cca.ufes.br

5 - Graduando em Agronomia, Aluno da Iniciação Científica, Depto. de Engenharia Rural, UFES. E-mail: jgmllere@hotmail.com

326 REVENG

326-337p.

ENGENHARIA NA AGRICULTURA, VIÇOSA - MG, V.24 N.4, JULHO / AGOSTO 2016 


\section{INTRODUCTION}

Pastures occupy approximately $25 \%$ of the land area, while Brazil has more than 200 million hectares of grassland, being largely composed of natural pastures. The forage plants usually receive no fertilization and, they lose their developmental potential over the years, reducing their quality and productivity. Thus, the use of nitrogen fertilizers aims at increasing the recovery of nitrogen applied to the soil-plant system, once besides the dry mass production, this nutrient promotes improved quality of forage produced and increased capacity of animals per area (BENNETT et al. 2008).

Brazil has area and environmental conditions favorable to the development of pastures, which in some cases are under degradation conditions, reducing the production of green mass and nutritional values for animal production. Another aspect is the tendency of the soil to the erosive effects, once the low vegetation cover provides areas of compression reducing the soil's water infiltration capacity (ZIMMER et al. 2002).

The natural water scarcity in some regions and that compounded by pollution of water bodies reduces the quantity and quality of this resource. Thus, considering the fate of clean water sources for human consumption, in recent years, the advancement of technical and scientific knowledge regarding the potential for water reuse contributed to the increased interest in the use of wastewater in agricultural crops (VILLELA JÚNIOR et al., 2003).

The growing volume of domestic sewage without treatment released in water bodies result of increased urban population along with the search for easy availability of water to serve these users promotes conditions of competition for this resource increasingly limited in its quality (COSTA et al., 2002; PAPAIOANNOU et al., 2006).

In search of new technologies to improve the production system with pastures, the fertigation with wastewater has been studied. In Brazil, works on reuse of effluents from cattle in cropping systems with forage grasses obtained satisfactory results regarding the increased quality and yield of forage (ERTHAL et al., 2010).
The growth of some forage species fertigated with swine effluent provided a significant increase in protein content, compared to those where only water from the supply system was applied (QUEIROZ et al., 2004). Similarly, the fertigation of pastures with swine manure have shown beneficial effects on the fertility and water retention in the soil after a time interval of effluent application, besides the increased soil biological activity (KONZEN, 2002).

Fonseca et al. (2007), McLaughlin et al. (2004) and Matos et al. (2003) observed that application of wastewater in systems planted with grasses can replace the clean water, since they are properly managed, providing increased quality and forage yield thus resulting in economic and environmental benefits.

Pereira Filho et al. (2009) found that the use of treated domestic sewage at doses of 150, 300, 600 and $1200 \mathrm{~kg} \mathrm{Na} \mathrm{ha-1}$ year $^{-1}$ may be used in fertigation of Tifton-85 without the need for supplementary fertilization in both first sections the grass. Alkhamisi et al. (2011) found that forage production with corn forage had greater proportions in yield, chlorophyll content, plant height and dry mass when treated wastewater was used in comparison to freshwater.

Mohammad and Ayadi (2004) observed that the macro and micronutrient absorption by corn fodder has increased with the use of treated domestic sewage, which means that this water source can be a source of plant nutrients and could be reused for purposes of fertigation by increasing forage production. Thus, the use of effluent on pasture via fertigation will allow the use of the nutrients contained in the effluent itself, favoring the development and increased fodder production (SANTOS et al., 2006) and therefore, reducing the use of mineral fertilizer.

Given the above, the objective of this work was to evaluate the yield and crude protein content of forages Tifton 85 (Cynodon spp.) and Marandu Grass (Brachiaria brizantha) fertigated with treated domestic sewage in four application rates under greenhouse conditions compared with those grown with mineral fertilizer. 


\section{MATERIAL AND METHODS}

The work was conducted in pots of 18 liters from June to August 2010 under greenhouse conditions in the experimental area of the Center of Agricultural Sciences of the Universidade Federal do Espírito Santo in the municipality of Alegre ES with geographical coordinates $20^{\circ} 45^{\prime}$, South latitude, $41^{\circ} 48^{\prime}$ 'West longitude and $147 \mathrm{~m}$ altitude.

The soil used in filling the pots was collected in the natural profile of a Typic where after collected, a sample was taken and sent to the laboratory for determination of chemical properties (Table 1), according to the methodology described by
Embrapa (2009).

After air-dried, deroasted, homogenized and passed through a sieve with $2 \mathrm{~mm}$ mesh, soil gad the acidity corrected by applying dolomitic limestone, increasing the base-saturation to $60 \%$, according to the recommendation proposed by Prezotti et al. (2007) for the state of Espírito Santo in fodder cultivation of high nutritional requirement.

Two experiments with completely randomized design were set, one with the forage Tifton 85 (Cynodon spp) and another with Marandu Grass (Brachiaria brizantha). Each experiment was conducted as split plot at $5 \times 3$ factorial arrangement with five replications. The factors in the plots

Table 1. Chemical properties of the soil used in the experiment after applying concealer to raise the base saturation

\begin{tabular}{lc}
\hline Characteristic & Amount \\
\hline $\mathrm{pH}$ water & 6.1 \\
Sulfur $\left(\mathrm{mg} \mathrm{dm}^{-3}\right)$ & 3.0 \\
Phosphorus $\left(\mathrm{mg} \mathrm{dm}^{-3}\right)$ & 2.0 \\
Potassium $\left(\mathrm{mg} \mathrm{dm}^{-3}\right)$ & 16.0 \\
Sodium $\left(\mathrm{mg} \mathrm{dm}^{-3}\right)$ & 15.0 \\
Calcium $\left(\mathrm{cmol}_{\mathrm{c}} \mathrm{dm}^{-3}\right)$ & 0.7 \\
Magnesium $\left(\mathrm{cmol}_{\mathrm{c}} \mathrm{dm}^{-3}\right)$ & 0.3 \\
Aluminium $\left(\mathrm{cmol}_{\mathrm{c}} \mathrm{dm}^{-3}\right)$ & 0.2 \\
H+Al $\left(\mathrm{cmol}_{\mathrm{c}} \mathrm{dm}^{-3}\right)$ & 2.5 \\
Carbon $\left(\mathrm{g} \mathrm{kg}^{-1}\right)$ & 1.7 \\
Organic Matter $\left(\mathrm{g} \mathrm{kg}^{-1}\right)$ & 2.9 \\
CTC effective $\left(\mathrm{cmol}_{\mathrm{c}} \mathrm{dm}^{-3}\right)$ & 5.8 \\
CTC total $\left(\mathrm{cmol}_{\mathrm{c}} \mathrm{dm}^{-3}\right)$ & 8.2 \\
Base Sun $\left(\mathrm{cmol}_{\mathrm{c}} \mathrm{dm}^{-3}\right)$ & 5.7 \\
Base Saturation $(\%)$ & 69.4 \\
Aluminium, $\mathrm{Saturation}(\%)_{\text {Sodium Saturation }(\%)}$ & 2.6 \\
Iron $\left(\mathrm{mg} \mathrm{dm}{ }^{-3}\right)$ & 0.8 \\
Copper $\left(\mathrm{mg} \mathrm{dm}^{-3}\right)$ & 220.0 \\
Zinc $\left(\mathrm{mg} \mathrm{dm}^{-3}\right)$ & 1.4 \\
Manganese $\left(\mathrm{mg} \mathrm{dm}^{-3}\right)$ & 2.5 \\
Boron $\left(\mathrm{mg} \mathrm{dm}^{-3}\right)^{1}$ & 15.0 \\
\hline I-Detas & 0.1 \\
\hline
\end{tabular}

1 - Determined by dry and reading calorimetry. 
corresponded to five treatments, one fertilized with mineral fertilizer in which was applied 40 $\mathrm{kg} \mathrm{ha}^{-1}$ of nitrogen and four fertigated with treated domestic sewage (TDS) at doses of 20, 40, 60 and $80 \mathrm{~kg} \mathrm{ha}^{-1}$ of nitrogen and in the subplots three production cycles made in sections of shoots of forage every 25 days. These doses corresponded to the application 3.5, 7.0, 10.5 and 14 liters of treated domestic sewage per pot.

The TDS used in the experiment was collected in the sewage treatment plant in the city of Jerônimo Monteiro-ES that uses upflow anaerobic sludge blanket and reactor (UASB Reactor type). For effluent's chemical characterization (Table 2), a $200 \mathrm{~mL}$ sample was collected and sent to the laboratory where electrical conductivity, $\mathrm{pH}$, total contents of nitrogen, phosphorus, potassium, calcium, magnesium, sodium, iron and boron were determined as described by Silva and Oliveira (2001).

The TDS was collected, transported in containers of $60 \mathrm{~L}$ and stored in a tank of $500 \mathrm{~L}$ inside the greenhouse. The TDS was taken directly from the reservoir through faucet and its application in experimental units was performed manually with the aid of one-liter measuring cylinder.

The planting of forage occurred in the first fortnight of June 2010, when the seedlings of Tifton 85 and marandu grass were transplanted in order to promote in each experiment the same density of plants in the experimental units. After 15 days of transplantation, there was a uniformity section in all plots.

The first 30 days after planting in pots, forages in experimental units were irrigated with water only, following a water balance in the soil based on three day-interval irrigation shift. Water management in the experiments was carried out by the method of weighing vessels where the difference corresponded to the mass and volume of water or effluent to be applied to increase the soil to the field capacity.

For the calculation of TDS doses, the nitrogen content was taken as a reference to establish the slides necessary for the application of different element doses as described in the experimental arrangement. In the experimental units that received TDS, there was a complementary chemical fertilization with phosphorus and potassium which was calculated by subtracting the amounts of these nutrients from the quantity coming from different depths of effluent applied to each corresponding treatment. In Table 3 there is the amount of nutrients transferred by means of each treatment.

Table 2. Chemical characterization of treated domestic sewage used during the experiment

\begin{tabular}{lc}
\hline Characteristics & Amount \\
\hline $\mathrm{pH}$ & 7.62 \\
Electrical Conductivity $\left(\mathrm{dS} \mathrm{m}^{-1}\right)$ & 0.51 \\
Potassium $\left(\mathrm{mg} \mathrm{L}^{-1}\right)$ & 14.84 \\
Sodium $\left(\mathrm{mg} \mathrm{L}^{-1}\right)$ & 9.2 \\
Chlorides $\left(\mathrm{mg} \mathrm{L}^{-1}\right)$ & 3.72 \\
Iron $\left(\mathrm{mg} \mathrm{L}^{-1}\right)$ & $<0.01$ \\
Phosphorus Total (mg L-1) & 1.85 \\
Nitrogen Total (mg L-1) & 57.0 \\
Calcium (mg L-1) & 56.1 \\
Magnesium (mg L-1) & 24.1 \\
Súlfur (mg L-1) & 0.09 \\
Sodium Adsorption Ratio $\left(\mathrm{cmol}_{\mathrm{c}}^{-1}\right)$ & 1.70 \\
\hline
\end{tabular}


Table 3. Nutrient amount $\left(\mathrm{kg} \mathrm{ha}^{-1}\right)$ contributed to the ground by means of each treatment during the trial period

\begin{tabular}{lccccccc}
\hline Dosage of N & Potassium & Sodium & Boron & Calcium & Magnesium & Sulfur & Phosphorus \\
\hline $20 \mathrm{~kg} \mathrm{ha}^{-1}$ & 4.64 & 3.62 & 3.02 & 9.16 & 8.46 & 0.04 & 6.32 \\
$40 \mathrm{~kg} \mathrm{ha}^{-1}$ & 9.28 & 7.24 & 6.04 & 18.32 & 16.92 & 0.08 & 12.64 \\
$60 \mathrm{~kg} \mathrm{ha}^{-1}$ & 13.92 & 10.86 & 9.06 & 27.48 & 25.38 & 0.12 & 18.96 \\
$80 \mathrm{~kg} \mathrm{ha}^{-1}$ & 18.56 & 14.48 & 12.08 & 36.64 & 33.84 & 0.16 & 25.28 \\
\hline
\end{tabular}

Soil fertilization and fertigation of forages with TDS were performed after 30 days of transplanting. The TDS application was made according to a three days watering shift until the total amount applied in each treatment. On average about 0.65 $\mathrm{L}$ of effluent were applied to each irrigation. In the treatment with conventional fertilization and after completion of treatments with TDS, the water content maintenance in the soil was carried out with application of water from the supply system.

The plant material of plots was sectioned manually with the aid of scissors at 25,50 and 75 days after transplanting. After each section, the mineral fertilization and application of treated domestic sewage were performed following the dosages established in each experimental plot.

The sectioned plant material used to estimate the yield of forage was harvested on area of 0.07 $\mathrm{m}^{2}$ and section was carried out at $0.05 \mathrm{~m}$ height from the ground surface. After cutting the shoots of grasses, they were weighed immediately to obtain the green mass yield. Then, the material was packed in paper bags previously identified and brought to a forced air circulation oven at $65^{\circ} \mathrm{C} \pm$ 2 for $72 \mathrm{~h}$ to determine the dry weight.

The dried material was ground in Willey mill type and placed in paper bags properly identified and forwarded to the laboratory for crude protein (CP) by multiplying the 6.25 factor by the value of nitrogen found as established by Galvani and Gaertner (2006).

The statistical analysis of characteristics of yield, dry matter and crude protein content in each experiment was performed by analysis of variance adopting $\alpha=5 \%$, considering the treatments in the split plots and sections in the subplots. To compare the mineral fertilization with treatments fertigated with treated domestic sewage in each section, it was made a contrast between means. On the other hand, the effect of TDS doses on the assessed characteristics was calculated by the Tukey's test and regression analysis at $5 \%$ probability.

\section{RESULTS AND DISCUSSION}

The yield, dry matter and crude protein content of Tifton 85 and marandu grass were influenced by the interaction among treatments applied and sections $(p<0.05)$. Based on the contrast between means of characteristics evaluated in both forages shown in Table 4, it seems that the yield, dry matter and crude protein content of Tifton 85 and marandu grass fertigated with TDS did not differentiate the mineral fertilization in the 1st section. However, in the 2nd and 3rd section of plants with fertigated TDS, the characteristics evaluated were higher than those obtained with chemical fertilizers.

The TDS fertigation on Tifton 85 promoted higher yield and dry matter in the 2nd section, followed by the 1st and 3rd section (Table 4). On the other hand, the mineral fertilization, yield and dry mass of Tifton 85 decreased with sections made. This fact demonstrates that the TDS application compared to mineral fertilization resulted in higher biomass production of Tifton 85 , allowing with the 2 nd section obtaining results superior to those obtained in the 1st section. Positive results relating the forage yield resulted from the application of effluents in the soil were checked by Erthal et al. (2010) who found that the application of $100 \mathrm{~kg} \mathrm{ha}^{-1}$ potassium via wastewater from cattle under conditions of drainage lysimeters planted with Tifton 85 promoted dry mass yield statistically similar to that obtained with chemical fertilizers. Matos et al. (2003) found that ryegrass, oats and millet grown in ramps for the treatment of wastewater from pulping of arabica coffee showed yield of dry matter and crude protein close to those obtained with the application of good quality water, supplemented with conventional

\section{REVENG} 326-337p. 
Table 4. Contrast between the average yield, dry matter and crude protein in Marandu grass and Tifton 85 the three cuts (every 25 days management) made on the basis of mineral fertilizer and irrigation average of four treatments with treated domestic sewage

\begin{tabular}{|c|c|c|c|c|}
\hline \multirow{2}{*}{ Cuts } & \multicolumn{2}{|c|}{ Tifton 85} & \multicolumn{2}{|c|}{ Marandu } \\
\hline & TDS fertigation & Mineral fertilizer & TDS fertigation & Mineral fertilizer \\
\hline & \multicolumn{4}{|c|}{-------------------------------- Yield $\left(\mathrm{kg} \mathrm{ha}^{-1}\right)$------------------------ } \\
\hline $1^{\mathrm{o}}$ & $3188.61 \mathrm{~B}$ a & $2977.22 \mathrm{~A} \mathrm{a}$ & $4364.72 \mathrm{~A}$ a & $4171.66 \mathrm{~A} \mathrm{a}$ \\
\hline $2^{\circ}$ & $4690.55 \mathrm{~A} \mathrm{a}$ & $2428.88 \mathrm{~B} \mathrm{~b}$ & $3835.00 \mathrm{~B}$ a & $2568.88 \mathrm{~B} \mathrm{~b}$ \\
\hline \multirow[t]{2}{*}{$3^{\circ}$} & $1923.33 \mathrm{C} \mathrm{a}$ & $1261.85 \mathrm{C} \mathrm{b}$ & $2671.85 \mathrm{C} \mathrm{a}$ & $1211.66 \mathrm{C} \mathrm{b}$ \\
\hline & \multicolumn{4}{|c|}{ - } \\
\hline $1^{\mathrm{o}}$ & $1206.66 \mathrm{~B}$ a & $1175.83 \mathrm{~A} \mathrm{a}$ & $1730.83 \mathrm{~A} \mathrm{a}$ & $1855.83 \mathrm{~A} \mathrm{a}$ \\
\hline $2^{\circ}$ & $1763.61 \mathrm{~A} \mathrm{a}$ & $925.00 \mathrm{~B} \mathrm{~b}$ & 1019.44 B a & $341.11 \mathrm{~B} \mathrm{~b}$ \\
\hline \multirow[t]{2}{*}{$3^{\circ}$} & $873.61 \mathrm{C} \mathrm{a}$ & $364.16 \mathrm{C} \mathrm{b}$ & $651.38 \mathrm{C} \mathrm{a}$ & $203.88 \mathrm{C} \mathrm{b}$ \\
\hline & \multicolumn{4}{|c|}{ 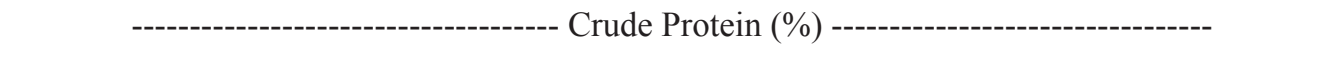 } \\
\hline $1^{\mathrm{o}}$ & $14.84 \mathrm{~A} \mathrm{a}$ & $14.54 \mathrm{~A} \mathrm{a}$ & $13.89 \mathrm{C} \mathrm{a}$ & $13.61 \mathrm{~A} \mathrm{a}$ \\
\hline $2^{\circ}$ & $14.73 \mathrm{~B} \mathrm{a}$ & $13.95 \mathrm{~B} \mathrm{~b}$ & $14.38 \mathrm{~B} \mathrm{a}$ & $13.41 \mathrm{Ab}$ \\
\hline $3^{\circ}$ & $14.21 \mathrm{~B} \mathrm{a}$ & $13.94 \mathrm{~B} \mathrm{~b}$ & $15.39 \mathrm{~A} \mathrm{a}$ & $13.57 \mathrm{~A} \mathrm{~b}$ \\
\hline
\end{tabular}

Means followed by the same uppercase and lowercase letters in columns and in rows within each forage, do not differ by Tukey test $(\mathrm{p}<0.05)$.

mineral fertilization. Likewise, similar results were obtained by Grattan et al. (2004), Mohammad and Ayadi (2004) and Adekalu and Okunade (2002).

In turn, yield and dry matter in maramdu grass fertilized with TDS and subjected to mineral fertilization decreased with the number of sections made. This result might be related to the supply of nitrogen under experimental conditions, since according to Novais et al. (1991), the container size has a direct influence on the exploitable soil volume reflecting the roots to absorb water and nutrients. Also, the input of organic matter and the subsequent gradual release of nutrients may have favored the development of the second cut besides the TDS can provide nutrients required in smaller quantities and which may not have been supplied by mineral fertilizers, such as micronutrients. Thus, even though being applied the amount of nitrogen required by forage, the low tillering reflected in reduced yields and dry matter. Similar results were obtained by Alexandrino et al. (2005), who when studying the growth and morphogenesis of marandu grass, observed tillering differences over time of regrowth influenced by nitrogen supply. According to these authors, plants not fertilized with nitrogen had low tillering, thus reducing productivity. In addition to this statement, Carvalho et al. (1991) obtained marked increases in dry matter production of Brachiaria decumbens when it was subjected to increasing levels of nitrogen up to $400 \mathrm{~kg} \mathrm{ha}^{-1} \mathrm{yr}^{-1}$.

Based on the result of contrast between means shown in Table 4, the crude protein content in the leaves of Tifton 85 obtained with TDS fertigation and mineral fertilization decreased with sectioning. In all sections of Tifton 85, crude protein greater than $7.0 \%$ was considered the minimum required by microorganisms in the rumen for adult cattle (NRC, 1989). As occurred for yield and dry matter of marandu grass, these results are related to the contribution of nitrogen under experimental conditions for Tifton 85, since Bennett et al. (2008) under field conditions, obtained increased crude protein content in Tifton 85 due to the increased dose of nitrogen applied to the soil, getting values close to $15 \%$ in the three sections at 30 days intervals. These results are superior to those obtained by Erthal et al. (2010) who found values between 6.37 to $14.75 \%$ in the 1 st and 4 th sections, respectively, using wastewater from cattle and also Menegatti et al. (2002) who obtained values ranging from 5.0 to $15.0 \%$.

Alkhamisi et al. (2011) found that corn 
plants forage fertigated with TDS showed higher percentage of crude protein $(12.08 \%)$ compared to those irrigated with freshwater (10.64\%). Similar results were reported by Silva et al. (2005) and Tavassoli et al. (2010).

The crude protein content of marandu grass increased with the number of sections of the plants when subjected to the TDS application; however, the results obtained in these treatments did not differ from those obtained with chemical fertilizers (Table 4). Probably, this result is due to the fact of nitrogen contained in the TDS has been released gradually, promoting a progressive availability compared to the mineral fertilizer used (ammonium sulfate), thus demonstrating that TDS fertigation provided increased protein content with the increased number of sections compared to the mineral fertilization. However, as occurred in Tifton 85, the crude protein of marandu grass in the treatments applied were above $7 \%$ providing good digestibility of the material ingested by animals.

Considering the three sections, the regression analysis showed a positive linear effect of TDS on yield, dry matter and crude protein of marandu grass and Tifton 85 (Figure 1 and Table 5). These results are related to the supply of nutrients, especially nitrogen and phosphorus, promoted by the increased doses of TDS. The results also indicate that the use of TDS in fertigation of Tifton 85 and grass marandu can contribute to the improvement of yield and nutritive value of these forages. These
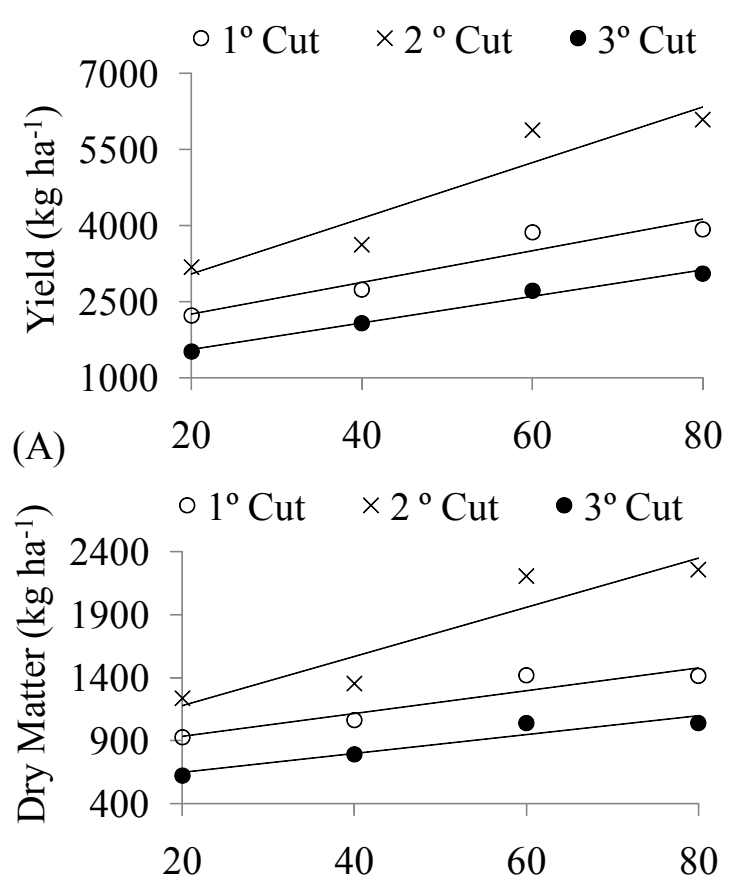

(B)

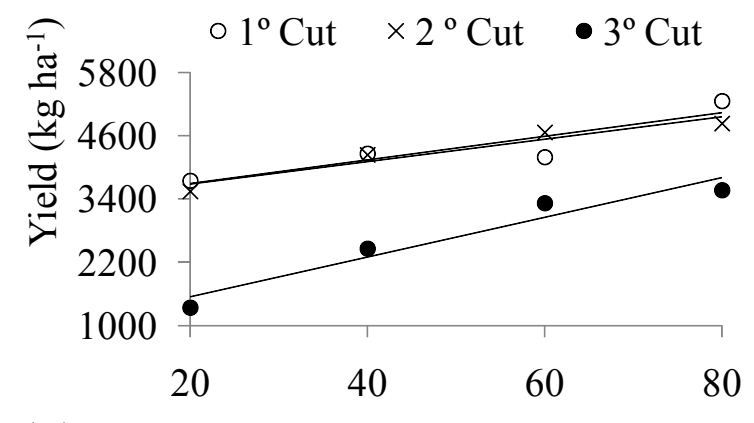

(D)

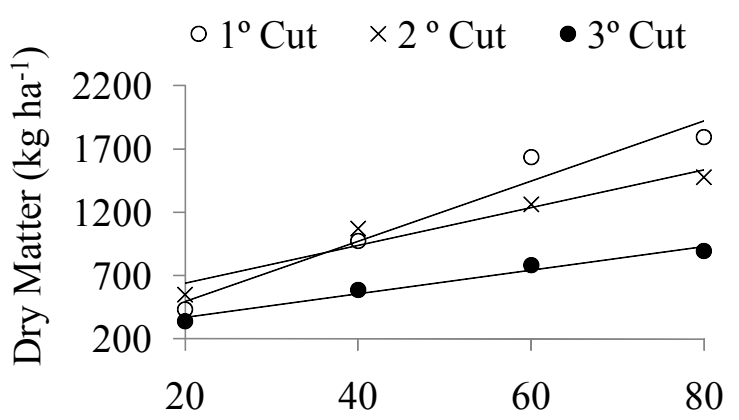

(E)
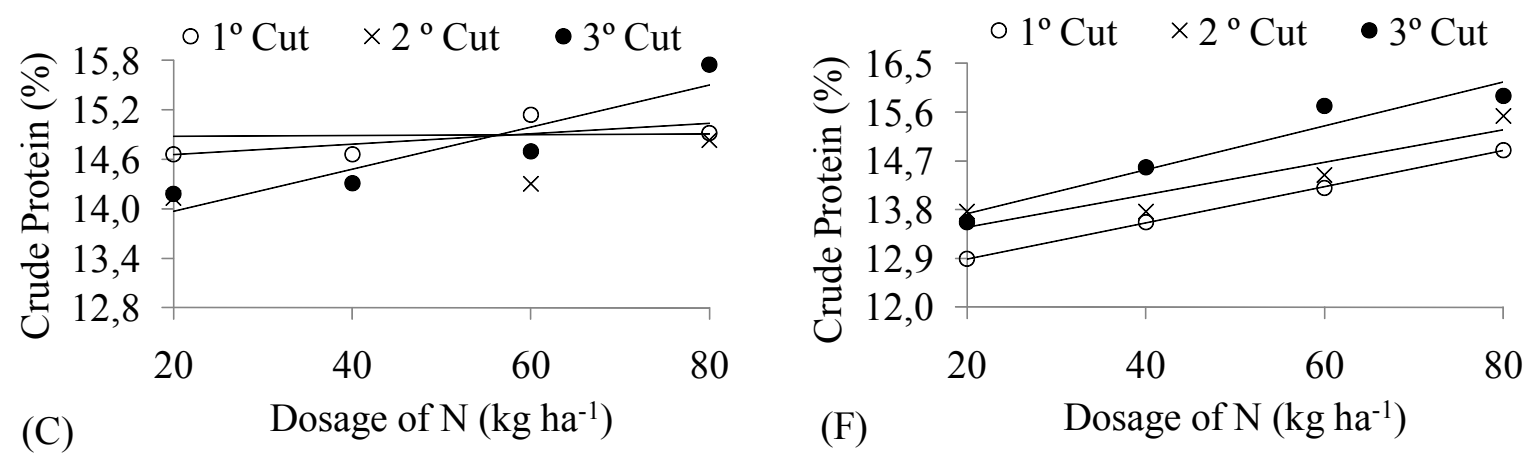

Figure 1. Yield, dry matter and crude protein, respectively, of Tifton 85 forage (A, B and C) and Grass Marandu (D, E and F) as a function of nitrogen applied through the treated domestic sewage on the recommendation for forage.

\section{REVENG 326-337p.}

ENGENHARIA NA AGRICULTURA, VIÇOSA - MG, V.24 N.4, JULHO / AGOSTO 2016 
Table 5. Adjusted equations related to the yield, dry matter and crude protein in Tifton 85 and Marandu grass function doses of nitrogen applied through treated domestic sewage in the three sections performed

\begin{tabular}{|c|c|c|c|c|}
\hline \multirow{2}{*}{ Cut } & \multicolumn{2}{|l|}{ Tifton 85} & \multicolumn{2}{|l|}{ Marandu } \\
\hline & Equation & $r^{2}$ & Equation & $\mathrm{r}^{2}$ \\
\hline \multicolumn{5}{|c|}{ 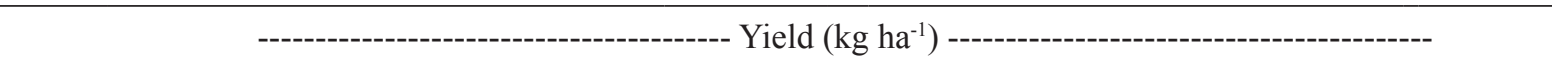 } \\
\hline $1^{\mathrm{o}}$ & $\hat{y}=1629.91+31.17^{*}$ Dosage & 0.9088 & $\hat{\mathrm{y}}=3244.77+22.39^{*}$ Dosage & 0.9088 \\
\hline $2^{\circ}$ & $\hat{y}=1954.54+90.86^{*}$ Dosage & 0.8882 & $\hat{y}=3251.11+21.41^{*}$ Dosage & 0.9299 \\
\hline $3^{\circ}$ & $\hat{y}=1026.84+26.24^{*}$ Dosage & 0.9854 & $\hat{y}=785.56+37.77^{*}$ Dosage & 0.9344 \\
\hline \multicolumn{5}{|c|}{ 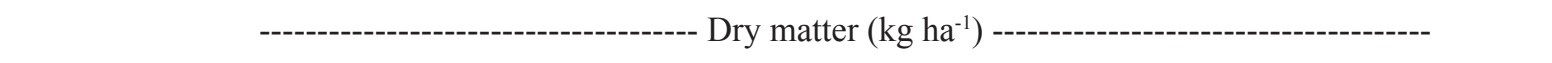 } \\
\hline $1^{\mathrm{o}}$ & $\hat{y}=756.11+9,01^{*}$ Dosage & 0.8834 & $\hat{y}=201.66+23.76^{*}$ Dosage & 0.9524 \\
\hline $2^{\circ}$ & $\hat{y}=758.56+19,56^{*}$ Dosage & 0.8643 & $\hat{y}=344.03+14.89^{*}$ Dosage & 0.9377 \\
\hline $3^{\circ}$ & $\hat{y}=499.58+7,48^{*}$ Dosage & 0.9001 & $\hat{y}=186.11+9.04^{*}$ Dosage & 0.9733 \\
\hline \multicolumn{5}{|c|}{ - } \\
\hline $1^{\mathrm{o}}$ & $\hat{y}=14.53+0.25^{*}$ Dosage & 0.7473 & $\hat{y}=12.22+1.33^{*}$ Dosage & 0.9991 \\
\hline $2^{\circ}$ & $\hat{y}=14.87+0.01^{*}$ Dosage & 0.7174 & $\hat{y}=12.87+1.98^{*}$ Dosage & 0.8564 \\
\hline $3^{\circ}$ & $\hat{y}=13.46+1.02^{*}$ Dosage & 0.8555 & $\hat{y}=12.91+1.26^{*}$ Dosage & 0.9344 \\
\hline
\end{tabular}

Significant at $5 \%$ probability.

results are consistent with those reported for Tifton 85 fertigated with wastewater from cattle (ERTHAL et al., 2010), treated domestic sewage (FONSECA et al., 2007; BELTRAN et al., 2008); Panicum maximum cv. Tanzania and Moçamba fertigated with carcinoculture effluent (MIRANDA et al., 2010) and elephant grass fertilized with swine wastewater (CABRAL et al., 2011).

According to the means test result shown in Table 6, the yield and dry mass of Tifton 85 within each TDS dose applied were higher in the 2nd section, followed by the 1 st and 3rd sections. However, the yield and dry matter content within each TDS dose decreased with the sections made in Marandu grass. Accordingly, the TDS application increased biomass production of Tifton 85 from the 2nd section, which did not occur to the Marandu grass. The decreased yield and dry mass of marandu grass and Tifton in the 2nd and 3rd sections are linked to increased tillering and plant density under experimental conditions. Thus, despite plants expressing their growth potential with TDS application, competition for light and nutrients within the experimental unit became stronger with the increased number of sections, resulting in decrease of the characteristics evaluated. These results are similar to those observed for Premazzi et al. (2003) and Premazzi et al. (2011) for Tifton 85, as well as Bennet et al. (2008) found that biomass production in Brachiaria brizantha tended to decrease when applied 179 and $141 \mathrm{~kg} \mathrm{ha}^{-1}$ nitrogen in the 2nd and 3rd sections, respectively.

The crude protein content shown in Table 6 and Tifton 85 were statistically equal in the 1 st and $3 \mathrm{rd}$ sections, being superior to those in the 2nd section at all TDS doses applied. In turn, the crude protein content was lower in the 1st section and higher on the 2nd and 3rd sections on Marandu grass in all TDS doses applied, which did not differ among each other. These results show that the nitrogen concentrations in plant tissue of Tifton 85 on the 1 st and 3rd sections and on 2nd and 3rd sections of marandu grass increased in response to TDS application, within each dose.

However, Table 6 shows that the highest crude protein values were obtained when both forages had lower yield. This result is associated with reduced fiber content, which is desirable, thus showing a positive effect of TDS application on the nutritive value of the fodder studied. Similar results were observed by Vielmo et al. (2011), where the percentage of crude protein had increased and that of fiber Tifton 85 decreased with increasing dose of swine wastewater, improving the forage nutritional value. The same occurred for Menegatti et al. (2002) and Gonçalves et al. (2003) for species of the genus (Cynodon sp.). 
Table 6. Mean values of yield, dry matter and crude protein in grass and Tifton 85 Marandu the three cuts made due to nitrogen applied through the treated domestic sewage on the recommendation for the forages

\begin{tabular}{|c|c|c|c|c|c|c|}
\hline \multirow{3}{*}{ Doses } & \multicolumn{3}{|c|}{ Tifton 85} & \multicolumn{3}{|c|}{ Marandu } \\
\hline & \multicolumn{3}{|c|}{ Cut } & \multicolumn{3}{|c|}{ Cut } \\
\hline & $1^{\circ}$ & $2^{\circ}$ & $3^{\circ}$ & $1^{\circ}$ & $2^{\circ}$ & $3^{\circ}$ \\
\hline & & \multicolumn{5}{|c|}{ 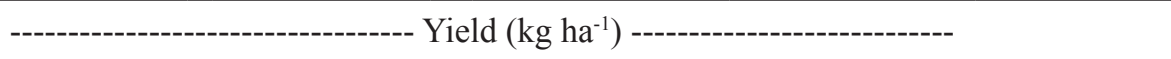 } \\
\hline 20 & $2225.83 \mathrm{~b}$ & $3179.72 \mathrm{a}$ & $1601.66 \mathrm{c}$ & $3747.22 \mathrm{a}$ & $2157.77 b$ & $1337.22 \mathrm{c}$ \\
\hline 40 & $2733.61 \mathrm{~b}$ & 3618.88 a & $2076.66 \mathrm{c}$ & $4263.05 \mathrm{a}$ & $3963.05 \mathrm{~b}$ & $2461.66 \mathrm{c}$ \\
\hline 60 & $3869.72 b$ & $5876.66 \mathrm{a}$ & $2716.11 \mathrm{c}$ & $4473.55 \mathrm{a}$ & $4109.72 \mathrm{~b}$ & $3321.66 \mathrm{c}$ \\
\hline 80 & $3925.55 \mathrm{~b}$ & $6087.22 \mathrm{a}$ & $3051.38 \mathrm{c}$ & $5258.05 \mathrm{a}$ & $4276.38 \mathrm{~b}$ & $3565.00 \mathrm{c}$ \\
\hline & & & Dr & $\left(\mathrm{kg} \mathrm{ha}^{-1}\right)--$ & --------- & \\
\hline 20 & $929,72 \mathrm{~b}$ & $1237,50 \mathrm{a}$ & $624,16 \mathrm{c}$ & $1542,77 \mathrm{a}$ & $547,50 \mathrm{~b}$ & $340,55 \mathrm{c}$ \\
\hline 40 & $1065,83 \mathrm{~b}$ & 1352,77 a & $790,83 \mathrm{c}$ & 1670,27 a & $1070,00 \mathrm{~b}$ & $585,83 \mathrm{c}$ \\
\hline 60 & $1417,77 \mathrm{~b}$ & $2207,22 \mathrm{a}$ & $1039,44 \mathrm{c}$ & 1636,94 a & $1261,11 \mathrm{~b}$ & $784,44 \mathrm{c}$ \\
\hline 80 & $1413,05 \mathrm{~b}$ & $2256,66 \mathrm{a}$ & $1040,00 \mathrm{c}$ & $2073,61 \mathrm{a}$ & $1199,16 \mathrm{~b}$ & $894,72 \mathrm{c}$ \\
\hline 20 & $14,66 \mathrm{a}$ & $14,13 \mathrm{~b}$ & $14,58 \mathrm{a}$ & $12,89 \mathrm{~b}$ & $13,76 \mathrm{a}$ & $13,57 \mathrm{a}$ \\
\hline 40 & 14,66 a & $13,61 \mathrm{~b}$ & $14,31 \mathrm{a}$ & $13,57 \mathrm{~b}$ & $15,46 \mathrm{a}$ & $15,58 \mathrm{a}$ \\
\hline 60 & $15,14 \mathrm{a}$ & $14,30 \mathrm{~b}$ & $14,70 \mathrm{a}$ & $14,20 \mathrm{~b}$ & $15,44 \mathrm{a}$ & $15,82 \mathrm{a}$ \\
\hline 80 & $15,62 \mathrm{a}$ & $14,83 \mathrm{~b}$ & $15,75 \mathrm{a}$ & $14,90 \mathrm{~b}$ & $5,53 \mathrm{a}$ & $15,40 \mathrm{a}$ \\
\hline
\end{tabular}

Means followed by the same lowercase and lowercase letters in columns in rows within each forage, do not differ by Tukey test $(\mathrm{p}<0.05)$.

Importantly, despite the positive effects on increasing biomass and crude protein content of forage resulting from TDS doses applied to the sections made, one cannot forget that the evaluation of forage should be made so that one can choose species that best adapted to growing conditions underwent fertigation with TDS. Therefore, the best performance should not be seen as the only purpose, and the nutritional value of forages is fundamental as it should allow the consumption of a food that meets the protein requirements of the animal body.

According to Erthal et al. (2010), the reference for defining the applications should not be calculated based on crop evapotranspiration, but on the soil-plant system ability to absorb the residue applied without compromising the quality of soil, plant or groundwater. In general, the contents of nitrogen, sodium, phytotoxic elements, heavy metals and salinity have been used as reference in the slide determination to be applied in fertigation and should be based on the component of highest concentration in the water.

Moreover, considering that the TDS used in the experiment is a byproduct of agronomic interest with real use potential in agricultural cultivation, besides the legislation, it must be complied with the appropriate dose of nutrients contained in the effluent to the type of soil and groundwater depth, as well as the technical guidelines based on the nutritional requirements of the culture installed. It must be used as a fertilizer, thus promoting a correct fade to this by-product, besides the advantages of reducing cropping costs.

\section{CONCLUSIONS}

- The TDS application used in the form of

\section{REVENG


fertigation compared with mineral fertilization provided increased yield, dry matter and crude protein in the $2^{\text {nd }}$ and 3 rd sections made in Tifton 85 and marandu grass;

- The increased TDS doses applied promoted the positive linear increase in yield, dry matter and protein content in Tifton 85 and marandu grass;

- The lowest values of yield and dry matter arising from the application of TDS doses reflected in higher crude protein contents and nutritive values of forages studied.

\section{REFERENCES}

ADEKALU, K.O.; OKUNADE, D.A. Effects of pond water and sewage effluent treatments on yield and nutrient uptake of maize (Zea mays L.). Tropical Agriculture, West Indies, v.79, n.2, p.120-124, 2002.

ALKHAMISI, S.A; ABDELRAHMAN, H.A; AHMED, M.; GOOSEN, M.F.A. Assessment of reclaimed water irrigation on growth, yield, and water-use efficiency of forage crops. Water Science, Oxford, v.1, p.57-65, 2011.

ALEXANDRINO, E.; NASCIMENTO JUNIOR, D.; REGAZZI, A.J.; MOSQUIM, P.R.; ROCHA, F.C.; SOUZA, D. Características morfogênicas e estruturais da Brachiaria brizantha cv. Marandu submetida a diferentes doses de nitrogênio e freqüências de cortes. Acta Scientiarum, Agronomy, Maringá, v.27, n.1, p.7-14, 2005.

APHA. AMERICAN PUBLIC HEALTH ASSOCIATION. Standard methods for the examination of water and wastewater. 19. ed. Washington: A.P.H.A.; A.W.W.A. and W.P.C.F., 1995. 1128p.

BELTRÃO, J.; SANTOS, R.; CORREIA, P.J. Combined effects of potassium and wastewater application on the yield and quality of Bermuda grass (Cynodon dactylon) in the Mediterranean regions. Wseas Transactions on Environment and Development. New York, v.4, n.9, p.726-735,
2008.

BENETT, C.G.S.; BUZETTI, S.; SILVA, K.S.; BERGAMASCHINE, A.F., FABRICIO, J.A. Produtividade e composição bromatológica do capim-marandu a fontes e doses de nitrogênio. Revista Ciência e Agrotecnologia, Lavras, 32, n. 5, 1629-1636. 2008.

CABRAL, J.R.; FREITAS, P.S.L.; REZENDE, R.; MUNIZ, A.S.; BERTONHA, A. Impacto da água residuária de suinocultura no solo e na produção de capim-elefante. Revista Brasileira de Engenharia Agrícola e Ambiental, Campina Grande, v.15, n.8, p.823-831, 2011.

CARVALHO, M.M.; MARTINS, C.E.; VERNEQUE, R.S.; SIQUEIRA, C. Resposta de uma espécie de braquiária à fertilização com nitrogênio e potássio em um solo ácido. Revista Brasileira de Ciência do Solo, v.15, n.2, 195-200, 1991.

COSTA, M.; BELTRAO, J.; DIONISIO, L.P.C.; GUERRERO, C.A.C.; BRITO, J.M.C.; MATOS, L.; REBELO, J.; GAMITO, P. Response of fairway grasses of golf courses to potable water irrigation as compared to wastewater application. Acta Horticulturae. Corbeekhoeve, v.573, p.357-362, 2002.

EMBRAPA - EMPRESA BRASILEIRA DE PESQUISA AGROPECUÁRIA. Manual de análises químicas de solos, plantas e fertilizantes. Brasília: Embrapa Comunicação para Transferência de Tecnologia. 2009, 627p.

ERTHAL, V.J.T.; FERREIRA, P.A.; PEREIRA, O.G.; MATOS, A.T. Características fisiológicas, nutricionais e rendimento de forrageiras fertigadas com água residuária de bovinocultura. Revista Brasileira de Engenharia Agrícola e Ambiental, Campina Grande, v.14, n.5, p.458-466, 2010.

FONSECA, A.F.; MELFI, A.J.; MONTEIRO, F.A.; MONTES, C.R.; ALMEID, V.V.; HERPIN, $\mathrm{U}$. Treated sewage effluent as a source of water and nitrogen for Tifton 85 bermudagrass. Agricultural 
Water Management, Amsterdam, v.87, p.328336, 2007.

GONÇALVES, G.D.; SANTOS, G.T.; JOBIM, C.C.; DAMASCENO, J.C.; CECATO, U.; BRANCO, A.F. Determinação do consumo, digestibilidade e frações protéicas e de carboidratos do feno de tifton 85 em diferentes idades de corte. Revista Brasileira de Zootecnia, Piracicaba, v.32, n.4, p.804-813, 2003.

GALVANI, F.; GAERTNER, E. Adequação da Metodologia Kjeldahl para determinação de Nitrogênio Total e Proteína Bruta. Brasília: EMBRAPA, 122p, 2006.

GRATTAN, S.R.; GRIEVE, C.M.; POSS, J.A.; ROBINSON, P.H.; SUAREZ, D.L.; BENES, S.E. Evaluation of salt-tolerant forages for sequential water reuse systems. I. Biomass production. Agricultural Water Management, Amsterdam, v.70, p.109-120, 2004.

KONZEN, E.A. Aproveitamento do adubo líquido da suinocultura na produção agropecuária. In: CONGRESSO NACIONAL DE IRRIGAÇÃO E DRENAGEM, 13., Uberlândia, Anais..., Minas Gerais: ABID, 2002. (CD-ROM).

MATOS, A.T.; PINTO, A.B.; PEREIRA, O.G.; SOARES, A.A.; LO MONACO, P.A. Produtividade de forrageiras utilizadas em rampas de tratamento de águas residuárias da lavagem e despolpa dos frutos do cafeeiro. Revista Brasileira de Engenharia Agrícola e Ambiental, Campina Grande, v.7, n.1, p.154-158, 2003.

MCLAUGHLIN, M.R.; FARBROTHER, T.E.; ROWE, D.E. Nutrient uptake by warm-season perennial grasses in a swine effluent spray field. Agronomy Journal, Madison, v.96, p.484-493, 2004.

MENEGATTI, D.P.; ROCHA, G.P.; FURTINI NETO, A.E.; MUNIZ, J.A. Nitrogênio na produção de matéria seca, teor e rendimento de proteína bruta de três gramíneas do gênero Cynodon. Revista Ciência e Agrotecnologia, Lavras, v.26, n.3, p.633-642, 2002.

MIRANDA， F.R.; CAVALCANTE， R.R.R.; RIBEIRO, E.M.; LIMA, R.N. Uso de efluentes da carcinicultura na irrigação de Panicum maximum cvs. Tanzânia e Mombaça. Revista Ciência Agronômica, Fortaleza, v.41, n.1, p.46-52, 2010. MOHAMMAD, M. J.; AYADI, M. Forage yield and nutrient uptake as influenced by secondary treated wastewater. Journal of Plant Nutrition, New York, v.27, p.351-364, 2004.

NOVAIS, R.F.; NEVES, J.C.L.; BARROS, N.F. Ensaio em ambiente controlado. In: Oliveira, A.J., De; Garrido, W.E.; Araujo, J.D.; Lourenço, S. Métodos de pesquisa em fertilidade do solo. Brasília: EMBRAPA-SEA, p.189-254, 1991.

NRC - NATIONAL RESEARCH COUNCIL, Nutrient requirements of dairy cattle. 6.ed., National Academy Press: Washington, 338p, 1989. PEREIRA FILHO, J.V.; SOUSA, C.C.M.; SILVA, A.R.A.; BEZERRA, F.M.L., Avaliação do capim Tifton-85 fertirrigado com águas residuárias de esgoto doméstico tratado. In: XII CONGRESSO BRASILEIRO DE FISIOLOGIA VEGETAL, 12., Fortaleza, Anais... Ceará: SBFV. CD-ROM.

PREMAZZI, L.M.; MONTEIRO, F.A.; CORRENTE, J.E. Tillering of Tifton 85 bermudagrass in response to nitrogen rates and time of application after cutting. Scientia Agricola, Piracicaba, v.60, n.3, p.565-571, 2003.

PREMAZZI, L.M.; MONTEIRO, F.A.; OLIVEIRA, R.F. Crescimento de folhas do capim-bermuda Tifton 85 submetido à adubação nitrogenada após o corte. Revista Brasileira de Zootecnia, Piracicaba, v.40, n.3, p.518-526, 2011.

QUEIROZ, F.M.; MATOS, A.T.; PEREIRA, O.G.; OLIVEIRA, R.A.; LEMOS, A.F. Características químicas do solo e absorção de nutrientes por gramíneas em rampas de tratamento de águas residuárias da suinocultura. Engenharia na Agricultura, Viçosa, v.12, n.2, p.77-90, 2004.

SANTOS, K.D.; HENRIQUE, I.N.; SOUSA, 
J.T; LEITE, V.D. Utilização de esgoto tratado na fertirrigação agrícola. Revista de Biologia e Ciências da Terra. Suplemento Especial, Capina Grande, n.1, p.1-7, 2006.

SILVA, P.R.F.; STRIEDER, M.L.; COSER R.P.S.; RAMBO, L.; SANGO L., ARGENTA, G.; FORSTHOFER, E.L; SILVA, A.A. Grain yield and kernel crude protein content Increases of maize hybrids with late Nitrogen side-dressing. Scientia Agricola, Piracicaba, v.62, n.5, p.487-492, 2005.

SILVA, A.A.; OLIVEIRA, R. Manual de análises físico-quimicas de águas de abastecimento e residuárias. Marcone: Campina Grande, 2001, 266 p.

TAVASSOLI, A.; GHANBARI, A.; AMIRI, E.; PAYGOZAR, Y. Effect of municipal wastewater wastewater with manure and fertilizer on yield and quality characteristics of forage in corn. African
Journal of Biotechnology, Sapele, v.9, n.17, p.2515-2520, 2010.

VIELMO, H.; BONA FILHO, A.; SOARES, A.B.; ASSMANN, T.S.; ADAMI, P.F. Effect of fertilization with fluid swine slurry on production and nutritive value of Tifton 85. Revista Brasileira de Zootecnia, Piracicaba, v.40, n.1, p.60-68, 2011.

VILLELA JUNIOR, L.V.E.; ARAÚJO, J.A.C.; FACTOR, T.L. Efeito da utilização do efluente de biodigestor no cultivo hidropônico do meloeiro. Revista Brasileira de Engenharia Agrícola e Ambiental, Capina Grande, v.7, n. p.72-79, 2003.

ZIMMER, A.; SILVA, M.P.; MAURO, R. Sustentabilidade e impactos ambientais da produção animal em pastagens. In PEIXOTO, M.A. Inovações Tecnológicas no Manejo de Pastagens. FEALQ, Piracicaba, p.31-58, 2002. 